\begin{abstract}
Iranica
Abstracta Iranica Revue bibliographique pour le domaine irano-aryen

Volume 32-33 | 2013

Comptes rendus des publications de 2009-2010
\end{abstract}

\title{
Lionel Bier. Palais B at Bishapur and its Sasanian Reliefs
}

\section{Bruno Overlaet}

\section{(2) OpenEdition \\ 1 Journals}

\section{Electronic version}

URL: http://journals.openedition.org/abstractairanica/40461

DOI: 10.4000/abstractairanica.40461

ISSN: 1961-960X

Publisher:

CNRS (UMR 7528 Mondes iraniens et indiens), Éditions de l'IFRI

\section{Printed version}

Date of publication: 1 December 2013

ISSN: 0240-8910

\section{Electronic reference}

Bruno Overlaet, "Lionel Bier. Palais B at Bishapur and its Sasanian Reliefs », Abstracta Iranica [Online], Volume 32-33 | 2013, document 141, Online since 01 July 2016, connection on 29 September 2020 URL : http://journals.openedition.org/abstractairanica/40461; DOI : https://doi.org/10.4000/ abstractairanica.40461

This text was automatically generated on 29 September 2020.

Tous droits réservés 


\title{
Lionel Bier. Palais B at Bishapur and its Sasanian Reliefs
}

\author{
Bruno Overlaet
}

\section{REFERENCES}

Lionel Bier. « Palais B at Bishapur and its Sasanian Reliefs », in : R. Gyselen, ed., Sources pour l'histoire et la géographie du monde iranien (224-710). Bures-sur-Yvette, 2009, p. 11-40. (Res Orientalis XVIII)

1 Palais B, the so-called "Valerian's palace", is a stone building on the northeastern side of Bishapur. It was first excavated by R. Ghirshman and G. Salles who discovered relief sculptures there. A. Sarfaraz followed up on these pre-World War II excavations briefly in 1974, when more sculpted blocks were dug up. The late Lionel Bier has combined the limited information existing on this palace with photographs and drawings of 25 blocks or block fragments with relief decorations, which he saw at the storage facilities in Bishapur. These reliefs portray equestrians, horses at rest and standing figures. The original positions of the blocks as well as the building's layout and function remain unknown. Based on a comparison with rock reliefs, Bier dates the sculptures to the period ranging from Shapur I (242-273) to Hormuzd II (302-309), and thus proposes a date for the building and the use of this stonework in Sasanian architecture. 


\section{AUTHORS}

\section{BRUNO OVERLAET}

Royal Museums of Art and History, Bruxelles 